\title{
TURPxit or not: contemporary management options for benign prostatic obstruction
}

\author{
Thomas R. W. Herrmann ${ }^{1,2,3} \cdot$ Vincent Misrai $^{4} \cdot$ Fernando Gómez Sancha ${ }^{5,6} \cdot$ Thorsten Bach $^{7}$
}

Published online: 20 July 2021

(c) The Author(s) 2021

The idea to the header of this special edition of the World Journal of Urology arose during the campaign for the 2019 election in United Kingdom, in a time of uncertainty on the further course of the European Union and its beloved relative from the isle.

This volume is meant to table a motion with regard to the topic of TURPxit. As in Brexit even 2021, it still remains unclear what exactly the TURPxiteers want to leave and want to substitute, furthermore, what the TURPsceptics feel uncomfortable about, and finally, what the remainers want to stay with in the end.

This might probably be because the acronym TURP seems to be descriptive but remains uncertain. To stay within the picture, Brexit makes perfectly sense with regard to the TURP template as the UK and Europe do speak of different

Thomas R. W. Herrmann

thomas.herrmann@stgag.ch

Vincent Misrai

vmisrai@clinique-pasteur.com

Fernando Gómez Sancha

fgomsan@gmail.com

Thorsten Bach

t.bach@asklepios.com

1 Urology Spital Thurgau AG, Pfaffenholzstrasse 4, 8501 Frauenfeld, Switzerland

2 Hannover Medical Scholl MHH, Carl Neuberg Str. 1, 30625 Hannover, Germany

3 Stellenbosch University Western Cape, Stellenbosch, South Africa

4 Department of Urology, Clinique Pasteur, 45 avenue de Lombez, Toulouse, France

5 Department of Urology and Robotic Surgery, ICUA-Clínica CEMTRO, Ventisquero de la Condesa 42, 28035 Madrid, Spain

6 Urology Department, Hill Clinic, Sofia, Bulgaria

7 Department of Urology, AsklepiosWestklinikumHamburg, Suurheid 20, 22559 Hamburg, Germany matters if they discuss TURP with a PSA reduction of $40 \%$ post-TURP for UK [1] and 58\% for Europe [2]. The view over the Atlantic which seemed so attractive for the Brexiteers is not providing harmonious consonance as the range for TURP templates goes down to $25 \%$ [3]. However, the expectations with regard to a former tempestuous greenish love seem to be different looking into Alex Te's data [4] with a PSA reduction post-photoselective vaporisation (PVP) of $17 \%$. If one is already happy with that-you definitely have a larger range of potentially satisfying solutions as a surgeon.

This special issue does not operate with divisive tactics, it is targeting that specific group of players who appreciate to have a look on a topic from different angles and find pleasure to hear the arguments of players in a technologyembracing field.

Urology is in love with technology and when it comes to being enamoured with something one still needs to master the evaluation whether it stands up to reality. [5] recently summarised what certainty of evidence is required for the implementation of novel techniques (Table 1). I would like to add to that - as he correctly mentioned that most of the established techniques fell short in providing the evidence before they became gold standards-if the concept/physics of the treatment is sound or if the marketing is just even sounder.

With regard to TURPxit, if you want to leave your old love, you should better examine the matter very carefully once again, and Räto Strebel and Steven Kaplan [6] have done this elegantly as the introduction to this issue. Even if the love for green seems to fade a little, the article of Kevin Zorn an colleagues [7] give an overview of the benefits of PVP vaporisation. As in any other field the enemy of what you might consider good is better, this is why Vincent Misrai and colleagues [8] and colleagues provided a comparison of vaporisation vs. enucleation by recontextualising the green light.

Sometimes reasons beyond first site make your old love look more attractive if you set up new objectives as the 
Table 1 Requirements for widespread implementation adapted from Speakman MJ et al. [5]

\author{
Concept/physics and anatomical considerations are sound \\ Proof of concept study \\ Placebo/sham comparison study \\ Randomised controlled trial against accepted alternative treatment \\ Cohort studies: to understand the generalisability and potential harms \\ Systematic reviews and meta-analysis of high-quality primary studies \\ How many patients should be included?-a sample size determination is needed \\ What should be the length of follow-up? \\ Short term: $<12$ months, medium 12-36 months and long term $>$ \\ 36 months \\ Inclusion and exclusion criteria need to allow good generalisability \\ Relevant outcomes-varied and need to be clearly outlined from the \\ start
}

main goal-away from durability. The topic in focus is the expectation of unchanged sexual function and namely antegrade ejaculation. Jean de la Rosette and colleagues [9] have added articles which scrutineers whether ejaculation is a valid endpoint or a conundrum. Although this manuscript is published online since 1st April, this article touches the core of relevance and probably reasons for existence in the nearer and further future of all so called new minimal invasive technologies (MIS).

Aquablation as a real-time image-guided therapy has gained substantial attention in the last years. Kevin Zorn and many fathers [10] of aquablation provide a summary on what the truth there is in this technology, today.

Although the results of multi-institutional UK-ROPE study [11] poured some acid in the wine of new shores of prostate arterial embolisation, Dominik Abt, Hans Peter Schmid and Mark Speakman [12] shed a light on the potential of this technique in their article.

If aquablation comes closest to what technology can achieve in future combined with artificial intelligence, the other aspired technique of today seems to keep the treatment in the hand of the steampunk prone surgeon in 2021. The available data off-site RCT against surgical comparator are explained by the third paper from Kevin Zorn and colleagues [13]. The group around Christian Gratzke [14] is summarising the rationale and evidence for the new MIS, namely iTIND, Urolift and Rezūm besides the shortcomings mentioned by Mark Speakerman in the above-mentioned article on certainty.

Robotic surgery is always in front when it comes to total procedural costs and total cost of investment. Therefore, it is in question whether in lack of RCT it should have a position aside anatomical enucleation of the prostate AEEP, as it clearly follows the principal of anatomical enucleation. In their article, Hubert John and Christian Pandevit from Winterthur as well as Christian Wagner and Jörn Witt from Gronau have [15] come to the conclusion that the time is right and provide a nice overview on robotic (simple) adenomectomy RASP.

The discussion on MIS of the 2016 till today mirrors in some aspects the discussion of the 2007 till 2016. The mayor difference is the anatomical clearly defined template on side of the AEEP and the extrananatomical template, which can be gradually modified on the side of the novel MIS.

The field of AEEP which has been pacified by the Magna Charta of AEEP (all anatomical enucleations are equally effective [16] has produced some interesting discussions with regard to superiority to other treatments on one hand and safety with regard to early functional results on the other, especially in the context of learning curve [17] [18].

The ground for the strife for better results is the preservation of intrasphincteral mucosa [19] and the influence of en bloc preparation vs two lobe or three-lobe technique in contemporary AEEP. An article penned from the group around one of the most experienced HoLEP Surgeons in the world, Karin Lehrich and colleagues [20] shed light on the topic of which seems to be-lobe wise-the best strategy after an estimated cumulative experience of more than 10,000 HoLEPs of the group of authors.

Tev Aho and colleagues [21] provided two articles on selected group of patients in AEEP, namely HOLEP in this case. The effectivity of AEEP as maximum deobstruction in patients with non-neurogenic chronic urinary retention seems to be ideally suited for patients with this condition. The other article about extra large prostates is pacing around the front line towards RASP, [22].

With the introduction of novel Thulium lasers that change the perception of Thulium in stone and soft tissue surgery Benedict Becker [23] and colleagues summarise the evidence for Thulium in AEEP in the light of new Thulium generators, be it fibre laser or novel YAG lasers. Since 2008, the debate whether Holmium or Thulium is the greater asset when it comes to AEEP is open. The group of Giorgio Bozzini [24] added another piece of information providing 
the data from a multicenter RCT comparing HoLEP with ThuLEP.

The data from bipolar enucleation have paved the way towards the overarching principle of AEEP in 2016 [25], [26]. As stated above, the quest for best energy source for each signature patients in AEEP is an ongoing debate. Lukas Lusuardi and colleagues [27] are revisiting that discussion in a systematic review of EEP-same but different.

The special issue of TURPxit or not-contemporary management options for benign prostatic obstruction ends with three personal articles. The first by Stavros Gravas, EAU Male Luts Guidelines chairman, [28] cast a view on the endourology as a field in motion thereby being endowed with the serenity of Greek philosophy of $\pi \alpha \dot{\alpha} \nu \tau \alpha \dot{\rho} \varepsilon \tilde{\tau}$. The second last editorial is contributed by guest editor [29] Fernando Gomez Sancha, highlighting quest from TURP to the best possible treatment for BPO-AEEP.

And last but not least as a closing remark: surgeon's heuristic and decision making in the face of all of the above displayed treatment options by guest editors Vincent Misrai and Thomas RW Herrmann [30].

We would like to cordially thank all contributors for the tireless efforts to enable such a nice collection of articles.

We wish all of you a pleasant reading of this special issue-which does not call for a general election of the best treatment, nor seeks a hard border in between the treatment option but keeps us united as endourological surgeons wanting to provide the best options for our patients.

Open Access This article is licensed under a Creative Commons Attribution 4.0 International License, which permits use, sharing, adaptation, distribution and reproduction in any medium or format, as long as you give appropriate credit to the original author(s) and the source, provide a link to the Creative Commons licence, and indicate if changes were made. The images or other third party material in this article are included in the article's Creative Commons licence, unless indicated otherwise in a credit line to the material. If material is not included in the article's Creative Commons licence and your intended use is not permitted by statutory regulation or exceeds the permitted use, you will need to obtain permission directly from the copyright holder. To view a copy of this licence, visit http://creativecommons.org/licenses/by/4.0/.

\section{References}

1. Green JS, Bose P, Thomas DP, Thomas K, Clements R, Peeling WB, Bowsher WG (1996) How complete is a transurethral resection of the prostate? Br J Urol. https://doi.org/10.1046/j.1464410x.1996.90813.x

2. Bachmann A, Tubaro A, Barber N, d'Ancona F, Muir G, Witzsch U, Grimm M-O, Benejam J, Stolzenburg J-U, Riddick A, Pahernik S, Roelink H, Ameye F, Saussine C, Bruyère F, Loidl W, Larner T, Gogoi N-K, Hindley R, Muschter R, Thorpe A, Shrotri N, Graham S, Hamann M, Miller K, Schostak M, Capitán C, Helmut Knispel
J, Thomas A (2015) A European multicenter randomized noninferiority trial comparing $180 \mathrm{~W}$ GreenLight XPS laser vaporization and transurethral resection of the prostate for the treatment of benign prostatic obstruction: 12 month results of the GOLIATH study. J Urol. https://doi.org/10.1016/j.juro.2014.09.001

3. Kasivisvanathan V, Hussain M (2018) Aquablation versus transurethral resection of the prostate: 1 year United States-cohort outcomes. Can J Urol. 25(3):9317-9322

4. Te AE, Malloy TR, Stein BS, Ulchaker JC, Nseyo UO, Hai MA (2006) Impact of prostate-specific antigen level and prostate volume as predictors of efficacy in photoselective vaporization prostatectomy: analysis and results of an ongoing prospective multicentre study at 3 years. BJU Int 97(6):1229-1233

5. Speakman MJ, Cornu JN, Gacci M, Gratzke C, Mamoulakis C, Herrmann TRW, Omar MI, Rieken M, Tikkinen KAO, Gravas S (2019) What Is the required certainty of evidence for the implementation of novel techniques for the treatment of benign prostatic obstruction? Eur Urol Focus 5(3):351-356. https://doi.org/10. 1016/j.euf.2019.05.014 (Epub 2019 Jun 14 PMID: 31204291)

6. Strebel RT, Kaplan SA (2021) The state of TURP through a historical lens. World J Urol. https://doi.org/10.1007/ s00345-021-03607-7

7. Schwartz RN, Couture F, Sadri I, Arezki A, Nguyen D-D, Zakaria AS, Law K, Elterman D, Rieken M, Cash H, Zorn KC (2020) Reasons to believe in vaporization: a review of the benefits of photoselective and transurethral vaporization. World J Urol. https://doi. org/10.1007/s00345-020-03447-x

8. Gasmi A, Khene Z-E, Guérin S, Bensalah K, Peyronnet B, Mathieu R, Roupret M, Rijo E, Pradère B, Misrai V (2021) Propensity-score analysis comparing perioperative and functional outcomes between XPS $180 \mathrm{~W}$-photovaporization and GreenLight laser enucleation of the prostate: reasons to discard vaporization and move to enucleation. World J Urol. https://doi.org/10.1007/ s00345-021-03590-z

9. GokhanCalik M, Laguna P, Gravas S, Albayrak S, de la Rosette J (2021) Preservation of antegrade ejaculation after surgical relief of benign prostatic obstruction is a valid endpoint. World J Urol. https://doi.org/10.1007/s00345-021-03682-w

10. Sadri I, Arezki A, Couture F, Nguyen D-D, Schwartz R, Zakaria AS, Elterman D, Rijo E, Misrai V, Bach T, Roehrborn CG, Zorn KC (2020) Reasons to overthrow TURP bring on Aquablation. World J Urol. https://doi.org/10.1007/s00345-020-03390-x

11. Ray AF, Powell J, Speakman MJ, Longford NT, DasGupta R, Bryant T, Modi S, Dyer J, Harris M, Carolan-Rees G, Hacking N (2018) Efficacy and safety of prostate artery embolization for benign prostatic hyperplasia: an observational study and propensity-matched comparison with transurethral resection of the prostate (the UK-ROPE study). BJU Int 122(2):270-282. https://doi.org/10.1111/bju.14249 (Epub 2018 May 6)

12. Abt D, Schmid H-P, Mark J (2021) Speakman Reasons to consider prostatic artery embolization. World J Urol. https://doi. org/10.1007/s00345-021-03601-z

13. Arezki A, Sadri I, Couture F, Schwartz R, Nguyen D-D, Zakaria AS, Elterman D, Roehrborn C, McVary K, Zorn KC (2020) Reasons to go for Rezūm steam therapy: an effective and durable outpatient minimally invasive procedure. World J Urol. https://doi.org/10.1007/s00345-020-03457-9

14. Suarez-Ibarrola R, Miernik A, Gratzke C, Schoeb DS (2020) Reasons for new MIS. Let's be fair: iTIND, Urolift Rezūm. https://doi.org/10.1007/s00345-020-03453-Z

15. John H, Wagner C, Padevit C, Witt JH (2021) From open simple to robotic-assisted simple prostatectomy (RASP) for large benign prostate hyperplasia: the time has come. World J Urol. https://doi.org/10.1007/s00345-020-03508-1 
16. Herrmann TR (2016) Enucleation is enucleation is enucleation is enucleation. World J Urol 34(10):1353-1355. https://doi.org/ 10.1007/s00345-016-1922-3 (Epub 2016 Sep 1)

17. Peyronnet B, Robert G, Comat V, Rouprêt M, Gomez-Sancha F, Cornu JN, Misrai V (2017) Learning curves and perioperative outcomes after endoscopic enucleation of the prostate: a comparison between GreenLight 532-nm and holmium lasers. World J Urol 35(6):973-983

18. Enikeev D, Morozov A, Taratkin M, Misrai V, Rijo E, Podoinitsin A, Gabdullina S, Herrmann TRW (2020) Systematic review of the endoscopic enucleation of the prostate learning curve. World J Urol. https://doi.org/10.1007/s00345-020-03451-1

19. Saitta G, Becerra JEA, Del Álamo JF, González LL, Elbers JR, Suardi N, Gómez-Sancha F (2019) 'En Bloc' HoLEP with early apical release in men with benign prostatic hyperplasia. World J Urol 37(11):2451-2458

20. Rücker F, Lehrich K, Böhme A, Zacharias M, Ahyai SA, Hansen J (2021) A call for HoLEP: en bloc vs. Two lobe vs. three-lobe. World J Urol. https://doi.org/10.1007/s00345-021-03598-5

21. Boxall NE, Georgiades F, Miah S, Dragos L, Armitage J, Aho TF (2021) A call for HoLEP: AEEP for mega-prostates $(\geq 200$ cc). World J Urol. https://doi.org/10.1007/s00345-021-03708-3

22. Aho T, Finch W, Jefferson P, Suraparaju L, Georgiades F (2021) HoLEP for acute and non-neurogenic chronic urinary retention: how effective is it? World J urol. https://doi.org/10.1007/ s00345-021-03657-x.Epub

23. Becker B, Netsch C, Bozzini G, Herrmann TRW, Bach T, Enikeev D, Gross AJ (2021) Reasons to go for thulium-based anatomical endoscopic enucleation of the prostate. World J Urol. https://doi.org/10.1007/s00345-021-03704-7

24. Bozzini G, Berti L, Aydoğan TB, Maltagliati M, Roche JB, Bove P, Besana U, Calori A, Pastore AL, Müller A, Micali S, Sighinolfi MC, Rocco B, Buizza C (2020) A prospective multicenter randomized comparison between holmium laser enucleation of the prostate (HoLEP) and thulium laser enucleation of the prostate (ThuLEP). World J Urol. https://doi.org/10. 1007/s00345-020-03468-6

25. Lin Y, Wu X, Xu A, Ren R, Zhou X, Wen Y, Zou Y, Gong M, Liu C, Su Z, Herrmann TR (2016) Transurethral enucleation of the prostate versus transvesical open prostatectomy for large benign prostatic hyperplasia: a systematic review and meta-analysis of randomized controlled trials. World J Urol 34(9):1207-1219

26. Arcaniolo D, Manfredi C, Veccia A, Herrmann TRW, Lima E, Mirone V, Fusco F, Fiori C, Antonelli A, Rassweiler J, Liatsikos E, Porpiglia F, De Sio M, Autorino R (2020) EAU Section of Uro-Technology (ESUT) Research Group Bipolar endoscopic enucleation versus bipolar transurethral resection of the prostate: an ESUT systematic review and cumulative analysis. World J Urol. https://doi.org/10.1007/s00345-019-02890-9

27. Pallauf M, Kunit T, Ramesmayer C, Deininger S, Hermann TRW, Lusuardi L (2021) Endoscopic enucleation of the prostate (EEP). The same but different-a systematic review. World J Urol. https://doi.org/10.1007/s00345-021-03705-6

28. Gravas S (2020) TURPxit or not: the guidelines perspective-Panta Rhei. World J Urol. https://doi.org/10.1007/s00345-020-03519-y

29. Gómez-Sancha F (2021) The constant search for the greater good: evolving from TURP to anatomic enucleation of the prostate is a safe bet. World J Urol. https://doi.org/10.1007/ s00345-021-03637-1

30. Misrai V, Herrmann TRW (2021) Surgeon's heuristics and decision making: a BPH storytelling. World J Urol. https://doi.org/10. 1007/s00345-020-03579-0

Publisher's Note Springer Nature remains neutral with regard to jurisdictional claims in published maps and institutional affiliations. 